\title{
A TUBERKULÓZIS ELŐFORDULÁSA EGY XVIII. SZÁZADI VÁCI CSALÁDBAN
}

\author{
Pap Ildikón ${ }^{1}$, Pálfi György², Molnár Erika², Karlinger Kinga ${ }^{3}$, K. Kovács Balázs ${ }^{3}$, \\ Korom Csaba ${ }^{3}$, Michael Schultz ${ }^{4}$, Tyede H. Schmidt-Schultz, ${ }^{5}$ Mark Spigelman ${ }^{6,7}$, \\ Helen D. Donoghue ${ }^{6,8}$, Kustár Ágnes ${ }^{1}$ és Szikossy Ildikó ${ }^{1,9}$
}

\begin{abstract}
${ }^{1}$ Magyar Természettudományi Múzeum, Embertani tár, Budapest; ${ }^{2}$ Szegedi Tudományegyetem, Természettudományi és Informatikai Kar, Embertani Tanszék, Szeged; ${ }^{3}$ Semmelweis Egyetem, Radiológiai és Onkoterápiás Klinika, Budapest; ${ }^{4}$ Department of Anatomy, University Medical School Göttingen, Göttingen, Németország; ${ }^{5}$ Department of Biochemistry, University Medical School Göttingen, Göttingen, Németország; ${ }^{6} \mathrm{Centre}$ for Clinical Microbiology, Division of Infection and Immunity, University College London, London, Egyesült Királyság; ${ }^{7}$ Department of Anatomy and Anthropology, Sackler Faculty of Medicine, Tel Aviv University, Tel Aviv, Izrael; ${ }^{8}$ Centre for the History of Medicine, Division of Biosciences, University College London, Egyesült Királyság; ${ }^{9}$ Szegedi Tudományegyetem, Természettudományi és Informatikai Kar, Biológia Doktori Iskola, Szeged
\end{abstract}

Pap I., Pálfi Gy., Molnár E., Karlinger K., K. Kovács B., Korom Cs., Schultz, M., SchmidtSchultz, H.T., Spigelman, M., Donoghue, H.D., Kustár Á., Szikossy I.: Tuberculosis cases in a Hungarian family, 18th century, Vác, Hungary. Two individuals of the Nigrovits family from the Vác Mummy Collection of the Hungarian Natural History Museum were the subjects of multidisciplinary, anthropological, paleopathological, radiological, paleomicrobiological and paleoproteomic studies. The father, Jozsef Nigrovits (No 29), died at the age of 55 on the 11th of November 1793; his son, Antal Nigrovits (No 54), died on the 16th of July 1803, at the age of 22. They lived in the 18th century in a small town of northern Hungary. The macroscopic examination of body No 54 showed a severely deformed neck and back region; body No 29 had no characteristic marks of any illnesses. The CT scan data of the bodies and their $3 D$ reconstructions showed no skeletal evidence of tuberculosis, despite the positive results of their paleomicrobiological studies. The deformity of body No 54 turned to be a developmental abnormality of unknown origin, but no Pott's gibbus was present.

Keywords: Mycobacterium tuberculosis; Paleopathology; Developmental abnormality; Paleomicrobiology; Natural mummies; 18th century; Vác; Hungary.

\section{Bevezetés}

A váci Fehérek templomának 1994-1995-ben zajlott felújítása közben fedezték fel a templom alatt elhelyezkedő kriptát. A leletmentést a váci Tragor Ignác Múzeum munkatársai végezték Susa Éva antropológus segítségével (Zomborka 1996).

A feltárás során előkerült koporsókból 265, halotti ruhába öltöztetett egyén mumifikálódott holtteste, valamint egy osszárium került elő (Tragor Ignác Múzeum 1995, Pap és mtsai 1997, Szikossy és mtsai 1997). A koporsókra festett évszámok, valamint az anyakönyvi bejegyzések tanúsága szerint a kriptát Vác lakosai, polgári és egyházi személyek használták 1731-1838 között. 
A feltárt koporsók és mellékletek a Tragor Ignác Múzeumba kerültek. Az antropológiai leleteket a Váci Püspökség hozzájárulásával a Magyar Természettudományi Múzeum Embertani tára őrzi.

A kriptába temetettek természetes úton konzerválódtak. A természetes mumifikálódást a kripta mikroklímája és a temetkezés módja tette lehetővé (Susa 1995, Susa és Józsa 1995, Pap és mtsai 1999).

A 265 egyén közül 166-nak ismerjük a nevét. A mikrotörténeti kutatások információval szolgáltak a családi és rokoni kapcsolatokra.

\section{Anyag és módszer}

A vizsgálat anyaga

Vizsgálatainkat a néhai Nigrovits család két tagjának, az apának és a fiának a maradványain végeztük.

Az apa, Nigrovits József. Szám: 29. Leltári szám: 2009.19.29. Név: Nigrovits József. Elhalálozási életkora: 55 éves. Meghalt: 1793. november 11-én. Feltárás időpontja: 1994. december 2. A koporsón szereplő felirat: Josephus Nigrovits anorum aetatis suae 55 / obiit die 11 Novembris Ano Domini 1793. A koporsón szereplő felirat fordítása: Nigrovits József életének 55. esztendejében/elhunyt 1793. november 11-én. A halotti anyakönyvi bejegyzés: nincs.

A fiú, Nigrovits Antal. Szám: 54. Leltári szám: 2009.19.54. Név: Nigrovits Antal. Elhalálozási életkora: 22 éves. Meghalt: 1803. július 16-án. Feltárás időpontja: 1995. január 16. A koporsón szereplő felirat: PD Antonius Nigrovits Caelebs Anorum 22 / Obiit 16 Iulii Ano 1803. A koporsón szereplő felirat fordítása: Nigrovits Antal nőtlen, életének 22. esztendejében / elhunyt 1803. július 16-án. A halotti anyakönyvi bejegyzés: nincs.

\section{Alkalmazott módszerek}

Radiológia. A testek makroszkópos megfigyelését követő radiológiai vizsgálatokat a Semmelweis Egyetem Radiológiai és Onkoterápiás Klinikáján (Budapest) végeztük. A Philips Brillance 16 spirál CT készülékkel $1 \mathrm{~mm}$-es szelet vastagságot alkalmazva a teljes testekről 1600-2500 felvétel készült. A nyers adatok felhasználásával a szeleteket HRCT módban rekonstruáltuk. Az utófeldolgozás (post-processing) során úgynevezett csontablakot használtunk. A 3 dimenziós (3D) virtuális rekonstrukció a Philips CT készülék beépített programjával készült.

Paleomikrobiológia. Korábbi kutatásunkban paleomikrobiológiai vizsgálatokat végeztünk a University College London munkatársaival együttmüködésben, amelynek során a Nigrovits család két tagját is elemeztük. Célunk a csontokban és a mumifikálódott szövetekben megőrződött Mycobacterium tuberculosis komplex DNS-ének kimutatása volt (Fletcher és mtsai 2003).

Az elemzés során az archaikus DNS (aDNS) kimutatására ajánlott protokollt követtük (O’Rourke és mtsai 2000), az eljárás különböző fázisait elkülönített helyiségekben végezve, a korábban megjelent munkákban (Fletcher és mtsai 2003, Donoghue és mtsai 2005) közzétettek szerint. Az eljárást röviden összefoglalva: kis mennyiségű zúzott vagy porított mintát proteináz K / EDTA-ban $56{ }^{\circ} \mathrm{C}$-on $1-4$ napig előemésztettünk. Egy alikvotot 0,1 M N-fenacil-tiazolium-bromiddal kezeltünk (Poinar és mtsai 1998), amely a korábbi kutatások szerint alkalmas a régen élt népességek emberi maradványaiból vett mintákban lévő DNS extrahálására. Ezután mindkét alikvotot guanidium-tiocianát- 
oldatban lizáltuk, szilikagél capture-t végeztünk, a maradék felülúszóból a DNS-t izopropil-alkohollal kicsapatva kinyertük, mostuk, majd a felhasználásig szárítottuk. A kontrollreakciókat minden esetben, rutinszerüen elvégeztük, az extrakciókat és az elemzéseket ismételtük.

A baktérium DNS-ének amplifikálását a korábban részletesen leírtak szerint végeztük (Fletcher és mtsai 2003, Donoghue és mtsai 2005). Az eljárást röviden összefoglalva: a M. tuberculosis komplex (MTBC) DNS maradványokat az IS6110 specifikus régió célzásával detektáltuk nested PCR alkalmazásával, amely első körben 123 bp-nyi amplikont, a második reakció során a célszekvenciát tartalmazó 92 bp (1. táblázat) PCR terméket adott. Qiagen Hotstar® Taq polimerázt és reagenseket (Qiagen, West Sussex, UK) használtunk. A negatív kontrollreakciókat minden esetben rutinszerüen elvégeztük. A PCR-termékeket elektroforézisnek vetettük alá, agaróz gélen futtattuk, etidiumbromiddal festettük, UV fénnyel tettük láthatóvá, majd Polaroid kamerával fényképeztük. Egy későbbi vizsgálat során az 54. számú múmia tüdőszövetét real-time (valósidejü) PCR alkalmazásával (Évinger és mtsai 2011) az IS1081 lókuszra specifikus primerekkel (1. táblázat) értékeltük újra.

Hisztológia, paleoproteomika. Mindkét egyénböl vettünk mintát a szövettani és paleoproteomikai vizsgálatokhoz. A 29. számú múmia bal borda darabját és egy csigolyatestet, az 54. számú múmia jobb szárkapocs csontjának középdarabját különítettük el. Valamennyi csont felszínét nagyító segítségével tekintettük át. A vékonyréteg csiszolatok Schultz (2001) módszerét használva készültek.

Mindhárom mintát az extracelluláris csontmátrix fehérjék kivonására és kimutatására is felhasználtuk (Schmidt-Schultz és Schultz 2004). Az esetek paleoproteomikai elemzése még folyamatban van.

1. táblázat. A vizsgálat során használt M. tuberculosis complex-specifikus oligonukleotid szekvenciák (primerek).

Table 1. M. tuberculosis complex-specific primers used in this study.

\begin{tabular}{lccc}
\hline $\begin{array}{l}\text { Név } \\
\text { Name }\end{array}$ & $\begin{array}{c}\text { Célszakasz } \\
\text { Target region }\end{array}$ & $\begin{array}{c}\text { Célszakasz mérete } \\
\text { Target size }\end{array}$ & $\begin{array}{c}\text { Oligonukleotid szekvenciája } \\
\text { Primer }\end{array}$ \\
\hline P1 & IS6110 & $123 \mathrm{bp}$ & 5'CTCGTCCAGCGCCGCTTCGG 3' \\
P2 & IS6110 & & 5'CCTGCGAGCGTAGGCGTCGG 3' \\
IS-3 & IS6110 & 92 bp & 5'TTCGGACCACCAGCACCTAA 3' \\
IS-4 & IS6110 & & 5'TCGGTGACAAAGGCCACGTA 3' \\
NF & IS1081 & $72 \mathrm{bp}$ & 5' TGATTGGACCGCTCATCG 3' \\
NR & IS1081 & & 5' CTTGATGGGGGCTGAAGC 3' \\
1081 Probe & IS1081 & & 5'-FAM-GGGCTACCGCGAACGCA-BHQ1-3' \\
\hline
\end{tabular}

\section{Vizsgálati eredmények}

Az apa, Nigrovits József (29. számú múmia)

Nigrovits Józsefet háton fektetve, fejét előre állítva, kezeit a hasa előtt keresztbe téve helyezték a koporsóba. Teste nagymértékben mumifikálódott. A fej az állkapocs kivételével jó állapotban konzerválódott. A nyak teljesen ép. A mellkas és a hasi régió 100\%-ban mumifikálódott. A testnedvek pangása miatt a hát területe kevéssé mumifikálódott, csontváz állagú. A végtagok bőrrel fedettek. 
Az orron fokozott faggyútermelésre utaló seborrhea, valamint maradandó értágulatok, rosacea okozta elváltozások láthatók (Cseplák és mtsai 2012, 2015).

A vizsgálható fogak épek, az életkornak megfelelő kopottságúak, a koronákon fogkő van.

A mellkas keskeny, kachektikus (1. ábra). A nyakon enyhe görbület figyelhető meg. A szabadon álló csigolyákon kismértékü hypervascularisatio nyomai figyelhetők meg, amelyek felvethetik a tuberkulózis lehetöségét (Pálfi és mtsai 2012; 2. ábra).

A paleomikrobiológiai vizsgálatok eredményei szerint a mellkasból vett minta pozitív volt a nested PCR (92 bp) eljárást alkalmazva, ugyanakkor negatív eredményt adott a single stage PCR (123 bp) módszer szerint. A hasi régióból vett minta negatív eredményt szolgáltatott.

Nigrovits József esetében a szövettani vizsgálatra kiemelt bordán és csigolyatesten makroszkópos elváltozás nem volt megfigyelhető. Mikroszkóp alatt a csigolyatest szivacsos állományában kismértékủ oszteoklaszt reszorpció nyomai láthatók.

A szivacsos állomány néhány csontgerendájában gyengén fejlett és részben újjáépült Howship-féle lakunák maradványai figyelhetők meg (3a-b. ábra). Ugyanakkor vannak olyan csontgerendák is, amelyek kifejezett oszteoklaszt reszorpciót mutatnak (3c. ábra). Ezek az elváltozások nem jellemzőek az ilyen korú egyének csontszerkezetére. Az idős kori oszteoporózisban általában nem mutathatók ki a Howship-féle lakunák. Ezért fennáll egy kezdeti gyulladásos folyamat valószínüsége, amely összefügghet a korai tuberkulózis fertőzéssel. A kompakt csontállomány rossz megtartási állapotának köszönhetően extracelluláris csontmátrix nem volt észlelhető.

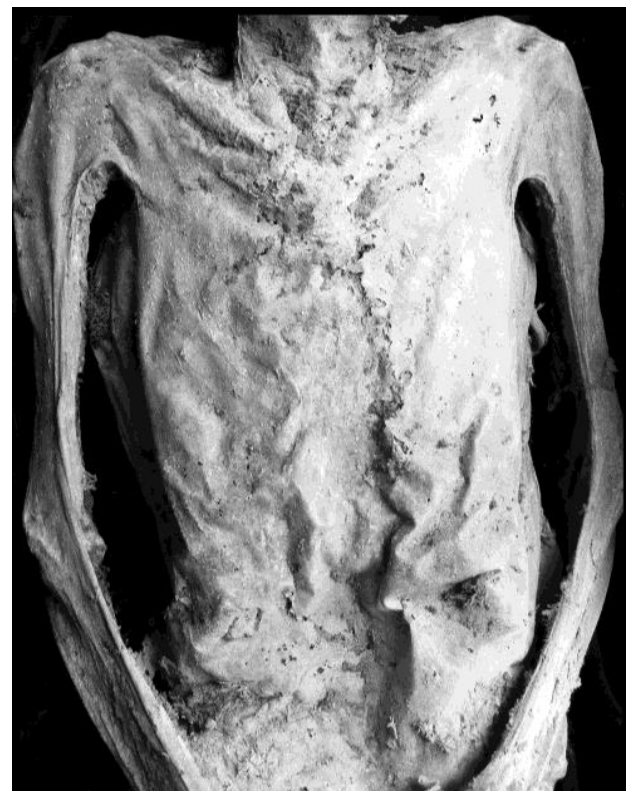

1. ábra: Nigrovits József (29. számú múmia) teste. A mellkas keskeny, kachectikus.

Fig. 1: Body of József Nigrovits (No 29). Cachectic, narrow chest.

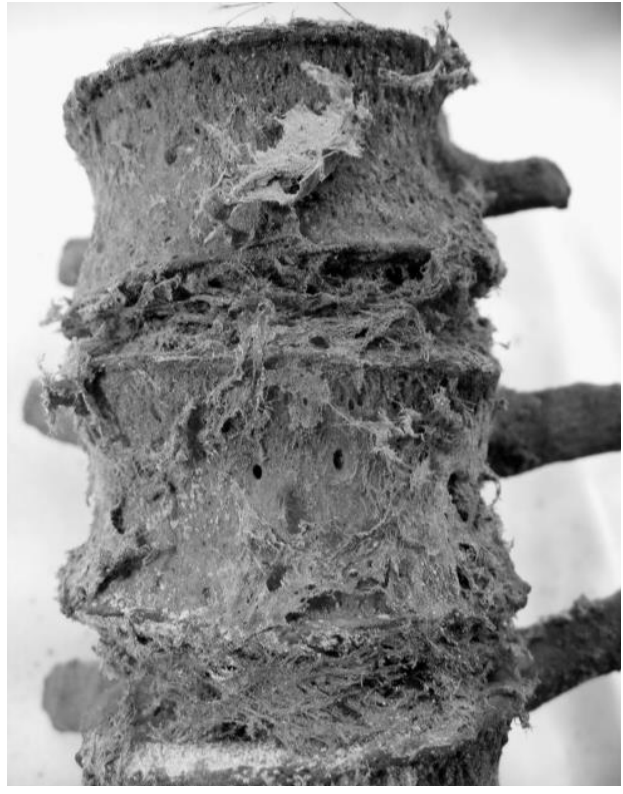

2. ábra: A szabadon álló csigolyákon kismértékü hypervascularisatio nyomai (29. számú múmia).

Fig. 2: Traces of slight hypervascularisation on the vertebrae (No 29). 

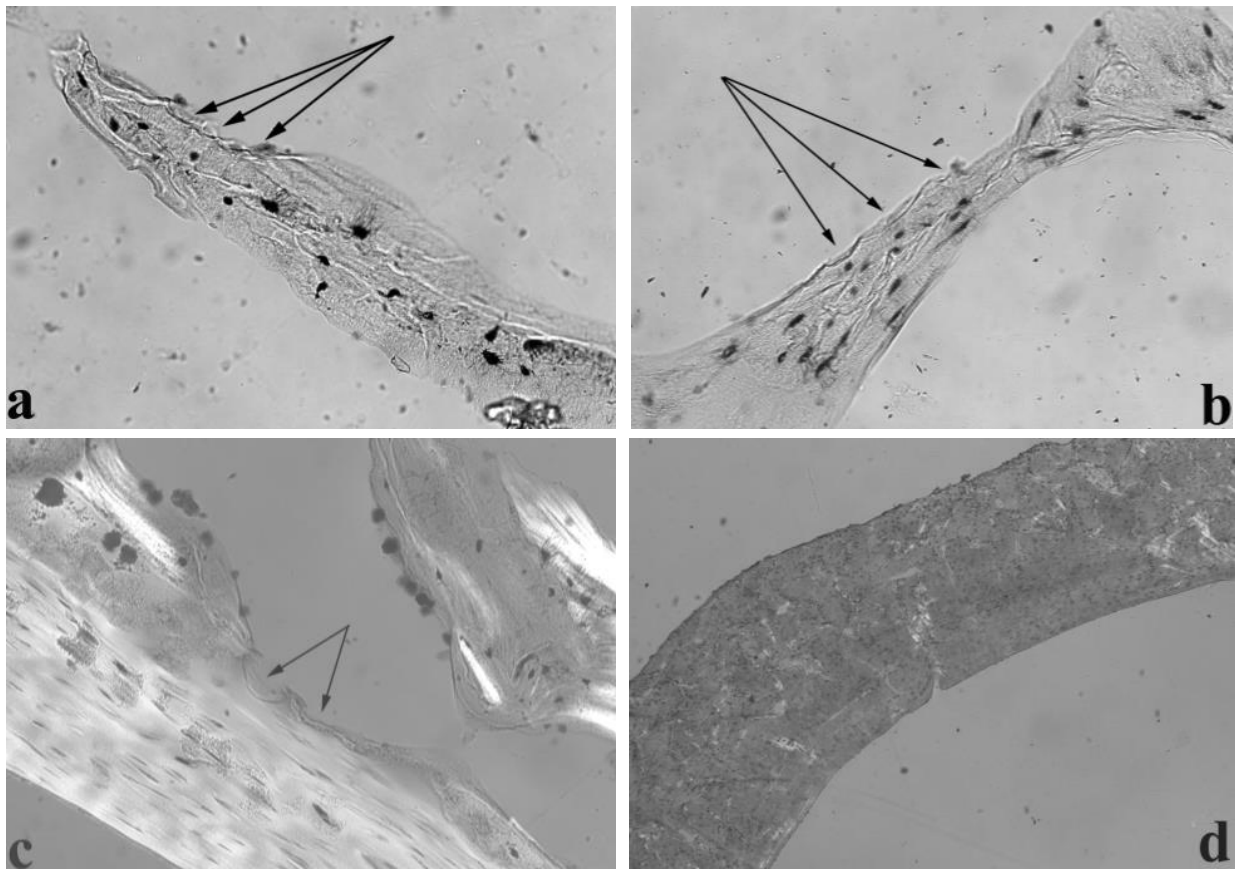

3. ábra: Nigrovits József (29. számú múmia), csigolyatest. Vékony-réteg csiszolat (70 ㅆm); a-b: transzmissziós, c: polarizációs mikroszkópos felvétel. 200x nagyítás. A nyilak a Howshiplakunákat mutatják. d: Nigrovits Antal (54. számú múmia) fibulája. A kompakt csontállomány lamelláris csontszerkezetében inaktivitásra utaló atrófia.

Fig. 3: Vertebral body of József Nigrovits (No 29). Thin-ground sections (thickness $70 \mu \mathrm{m}$ ); $\mathrm{a}-\mathrm{b}$ : viewed in plain, c: viewed in polarized light. Magnification 200x. Arrows points to Howship's lacunae; d: Fibula of Antal Nigrovits (No 54). Inactivity atrophy in the lamellar structure of the compact bone substance.

A fiú, Nigrovits Antal (54. számú múmia)

Nigrovits Antalt háton fektetve, fejét baloldalra hajtva, kezeit a hasa előtt keresztbe téve helyezték a koporsóba. A test részlegesen mumifikálódott. A fej bal oldala jó állapotban örződött meg, jobb oldala csontos. A nyak lágy szövetei elenyésztek. A mellkas és a hasi régió 70\%-ban mumifikálódott. A hát területének megtartása rossz, csontváz állagú. A végtagokat csontokra feszült, vékony bör fedi.

A vizsgálható fogak koronáin jelentös mennyiségü fogkő látható. A jobb felső második metszőfogon nagyfokú zománc hypoplasia figyelhető meg. A mandibula jobb oldalán több fogat érintő (I2-C-P1) pre mortem foghiány van. A jobb oldalon szabad szemmel nem vizsgálható a fogazat.

Az ifjú sovány testalkatú volt. A mellkas feltünően szük és keskeny, kachektikus (4. ábra). A gerinc nyaki és háti szakaszán nagyfokú deformitás, görbület figyelhető meg, amely felveti a tuberkulózis lehetőségét (5-6. ábra). A csigolyák többsége a mumifikálódás következtében szabad szemmel nem vizsgálható.

A CT adatok felhasználásával megalkottuk a deformált gerincoszlop virtuális 3D-s modelljét, azért, hogy megvizsgálhassuk az érintett csontok elváltozásait. A nyaki és ágyéki 
gerincen kisebb mértékü, a háti gerincen nagymértékü (60 foknál nagyobb) scoliosis figyelhető meg. A nyaki és a háti szakaszon kyphosis is észlelhető (7. ábra). A súlyos deformációt fejlődési rendellenesség okozta és nem csonttuberkulózis.

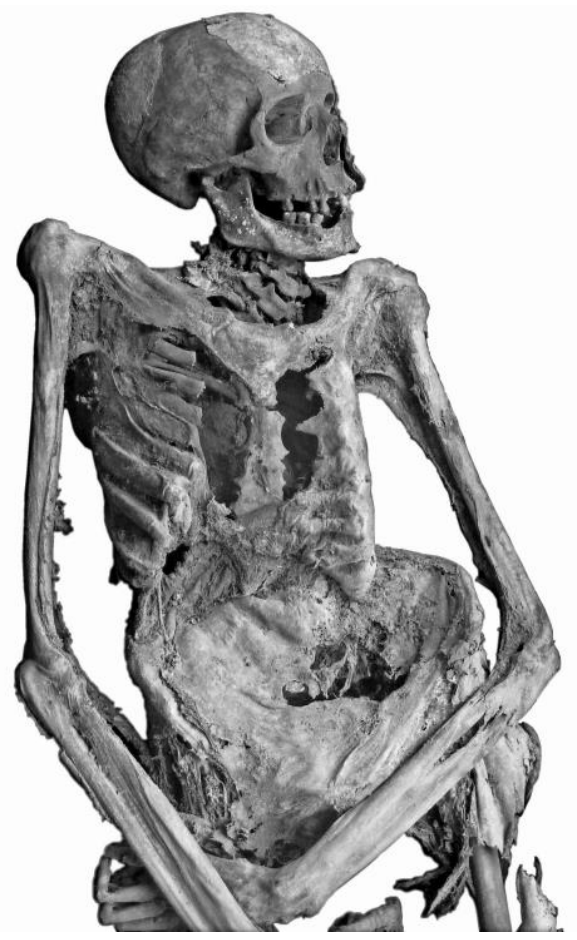

4. ábra: Nigrovits Antal (54. számú múmia) kachektikus teste.

Fig. 4: Cachectic body of Antal Nigrovits (No 54).

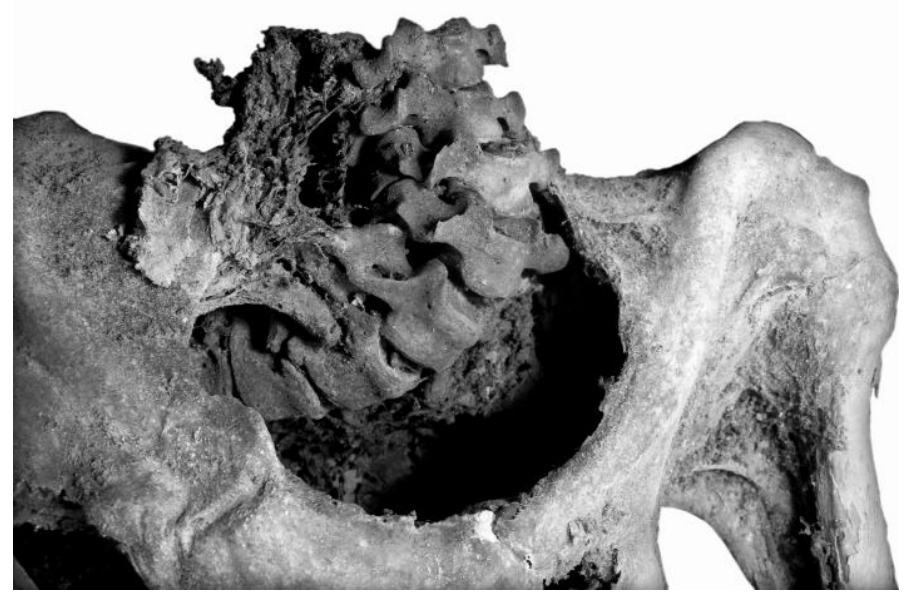

5. ábra: Deformálódott nyaki régió, közeli kép (54. számú múmia). Fig. 5: Deformed neck, a closer look (No 54). 


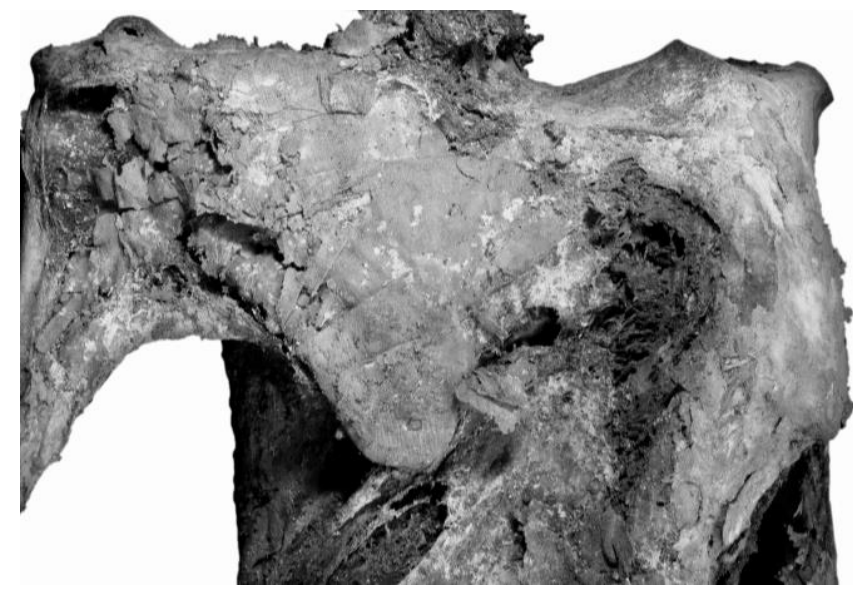

6. ábra: Nagy mértékben deformálódott hát (54. számú múmia). Fig. 6: Extremely deformed back (No 54).

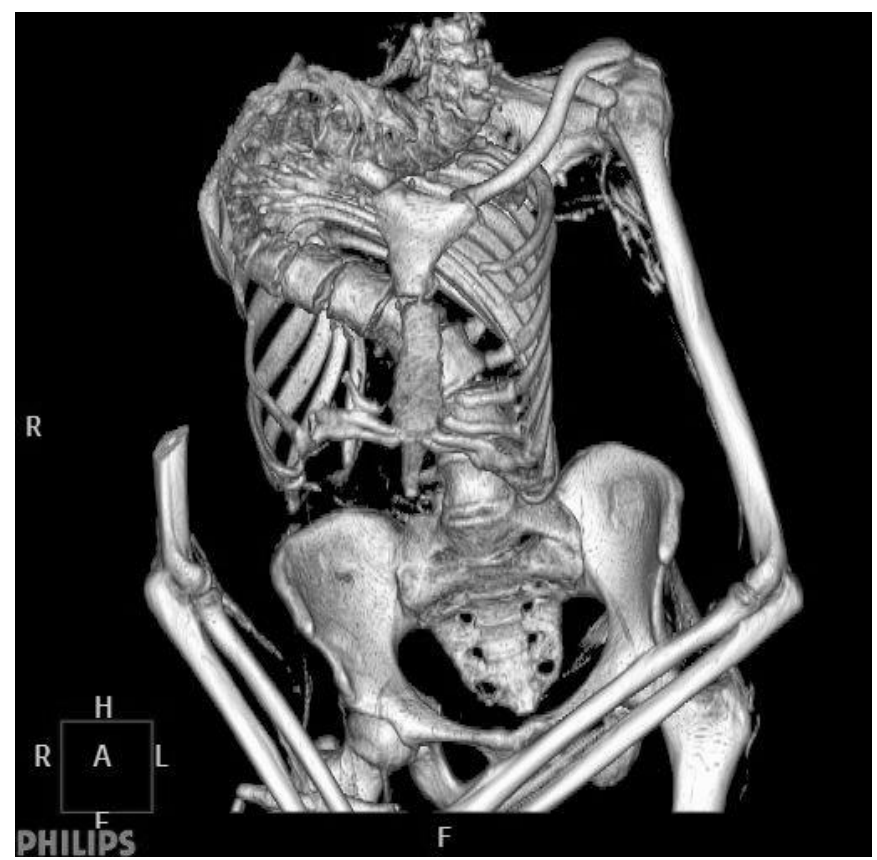

7. ábra: A nyaki és háti régió virtuális 3D-s rekonstrukciója (54. számú múmia).

Fig. 7: Virtual 3D model of the neck and back region using the CT scan data (No 54).

A korábban elvégzett paleomikrobiológiai kutatások eredménye szerint a tüdőszövetből és a has bal oldalából vett minták egyaránt negatív eredményt mutattak. Ugyanakkor a has egy másik részéből származó minta a nested PCR-ral (92bp) erős pozitív, a single stage PCR-ral (123 bp) negatív eredményt adott. Az újravizsgált tüdőszövetekből kinyert DNS-extraktum valamennyi frakciója a real-time PCR alkalmazásával az IS1081 lókuszra specifikus primerekkel negatív eredményt adott. 
Nigrovits Antal fibulája alapvetően nem mutatott semmilyen kóros elváltozást. Azonban a diafízis mediális oldalának kompakt állományában a lamelláris csontszerkezetben inaktivitásra utaló atrófia észlelhető (3d. ábra). Az elváltozás hosszú idejü ágyhoz kötöttségre utal. Ezt valamilyen krónikus betegség, például a tüdő tuberkulózis is eredményezhette. Ugyanakkor más lehetséges ok is szóba jöhet.

A fibula diafízis töredékében extracelluláris csontmátrix fehérjék, például oszteonektin és IgG mutatható ki. Ugyanakkor nem találtunk a tuberkulózisra jellemző specifikus fehérjéket (például Ag85).

\section{A vizsgálati eredmények értékelése}

A 29. számú egyén szemmel láthatóan kachektikus volt. A nyakon enyhén patológiás görbület, a szabadon álló csigolyákon kismértékü hypervascularisatio nyomai figyelhetők meg, amelyek felvethetik a tuberkulózis lehetőségét. Bár a mellkasi radiológiai felvételeken nem mutatkoztak rendellenességek, a mellkasból származó csontminta a nested PCR-vel (92 bp) tuberkulózisra pozitívnak bizonyult. A hasból vett szövetminta negatív volt. A mellkasi minta pozitivitása tüdő tuberkulózist sugall. Bár a szövettani vizsgálatra kiemelt bordán és csigolyatesten szabad szemmel nem észlelhető gyulladásra utaló elváltozás, a paleohisztológiai vizsgálatok eredményei korai TBC-s fertőzéshez köthetö, kezdeti gyulladásos folyamatra utalnak.

Az 54. számú egyén esetében a nyak és a hát szabad szemmel is észlelhető súlyos deformitása, valamint a mellkas és az egész test kachektikus megjelenése tuberkulózisra utal. A radiológiai képek tanúsága szerint a súlyos deformációt nem csonttuberkulózis eredetü Pott-gibbus, hanem fejlödési rendellenesség okozta.

A paleomikrobiológiai vizsgálat pozitív eredményt adott a nested PCR (92bp) eljárás alkalmazásával, de csak a hasi szövet esetében. Bár az összes többi minta és alkalmazott módszer negatív eredményt mutatott, a hasi minta pozitivitása aktív tuberkulózisfertőzésre utal. A hasi minta pozitivitása azt jelezheti, hogy a köpet (sputum) lenyelése megfertőzte az emésztörendszert. A paleohisztológiai eredmények is krónikus betegségekre utalnak, amely akár tüdőtuberkulózis is lehetett.

$\mathrm{Az}$ 54-es számú múmia esete hasonló egy korábban vizsgált másik váci múmia esetéhez. Tauber Antónia (97. szám) hátán látható súlyos gerinc deformitás felvetette a Pott-gibbus lehetőségét. A radiológiai képek ismeretlen eredetü, súlyos fejlődési rendellenességet, idiopátiás scoliosis mutattak (8. ábra). A molekuláris biológiai vizsgálatok kimutatták az MTBC DNS jelenlétét. A kórokozó bár jelen volt a testben, nem alakította ki a TBC-re jellemző csontelváltozásokat (Kustár és mtsai 2011a, b).

A becslések szerint a csontvázat érintő tuberkulózis általában mintegy $40 \%$-a érinti a gerincet (Aufderheide és Rodriguez-Martin 2008). Fontos azonban hangsúlyozni, hogy a gerinctuberkulózis viszonylag ritka. Természetes lefolyása szerint csak 3-5\%-ban alakul ki, és az esetek túlnyomó többségében nem valószínü, hogy csontvázon nyomot hagyó elváltozásokat okoz. Ezért a tuberkulózis előfordulása kétségtelenül jóval magasabb a történeti népességekben, mint amennyit a paleopatológusok észlelnek a csontokat érintő elváltozások alapján (Donoghue 2008).

A 29. és 54. számú új esetek (Szikossy és mtsai 2015), valamint a korábban vizsgált 97. számú váci múmia (Kustár és mtsai 2011a, b) példája alátámasztja azt a korábbi megfigyelést, hogy a TBC DNS-e morfológiai elváltozásokat nem mutató csontokban is kimutatható (Zink és mtsai 2001, Dutour 2008). 


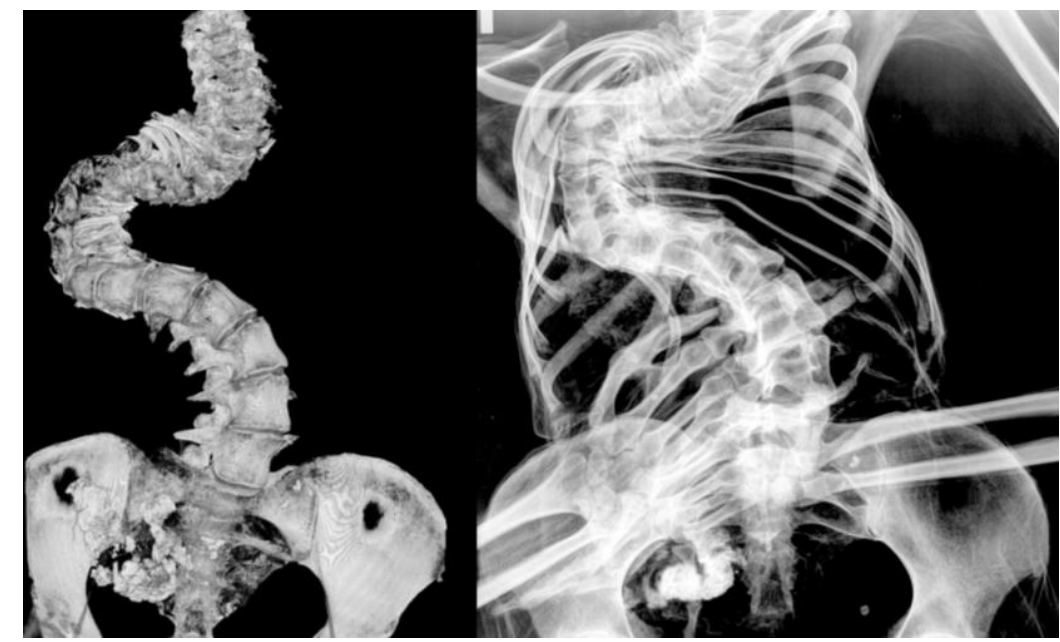

8. ábra: A röntgenfelvétel és a virtuális 3D-s rekonstrukció jól mutatja a nagymértékben deformálódott testet (97. számú múmia, Tauber Antónia).

Fig. 8: X-Ray picture and virtual 3D model of the extremely deformed body (Antónia Tauber, No 97).

\section{Következtetések}

A tanulmány a Magyar Természettudományi Múzeum Embertani tára Múmia Gyüjteményében őrzött Nigrovits család két tagjának mumifikálódott maradványain végzett multidiszciplináris, antropológiai, paleopatológiai, radiológiai, paleomikrobiológiai és paleoproteomikai vizsgálatok eredményeit mutatja be. A családfő, Nigrovits József (No. 29), 55 esztendős korában, 1793. november 11-én; fia, Nigrovits Antal (No. 54), 1803. július 16-án, 22 éves korában hunyt el. Mindketten Vácott, az észak-magyarországi kisvárosban éltek a XVIII. században.

A makroszkópos vizsgálatok eredménye szerint az apa (29. számú múmia) csigolyáin kismértékü elváltozások észlelhetők. A fiú (54. számú múmia) nyaki és háti gerincszakaszán szabad szemmel is látható, súlyos deformáció látható. A CT-vizsgálat és a 3D-s rekonstrukció egyik test esetében sem mutatott semmilyen tuberkulózisra utaló elváltozást, ugyanakkor a paleomikrobiológiai vizsgálatok pozitív eredményt szolgáltattak. A fiú testén a CT felvételeken mutatkozó deformitás nem a tuberkulózisra jellemző Pott-gibbus, hanem ismeretlen eredetü fejlődési rendellenesség következtében kialakult púp. Esete hasonló egy korábban vizsgált és ismertetett váci múmia (97. számú egyén, néhai Tauber Antónia) testén észlelt elváltozáshoz. A 29. és 54. számú, valamint a korábban vizsgált 97. számú váci múmia esete alátámasztja azt a korábbi megfigyelést, hogy a TBC archaikus DNS-e morfológiai elváltozásokat nem mutató csontokban is kimutatható.

Köszönetnyilvánítás: Köszönjük Vellainé Dr. Takács Krisztina tanszékvezető asszonynak a paleomikrobiológiai vizsgálatok során alkalmazott módszerek magyar nyelvre ültetésében nyújtott segítségét. A kutatás az OTKA 61155, OTKA K 73441 és 78555 és az NKFIH K 125561 projektek támogatásával valósult meg. 


\section{Irodalom}

Aufderheide, A., Rodriguez Martin, C. (2008): The Cambridge Encyclopedia of Human Paleopathology. Cambridge University Press, Cambridge. pp. 480.

Cseplák, Gy., Pap, I., Szikossy, I. (2015): A váci múmiákról - Antropo-medicinális tanulmányok 52 váci múmia vizsgálatáról egy bőrgyógyász fényképes jegyzeteivel. Semmelweis Kiadó és Multimédia Stúdió Kft., Budapest. p. 212.

Cseplák, Gy., Szikossy, I., Pap, I. (2012): Rosacea a XVIII. században. Börgyógyász Info, 8(4): 94-95.

Donoghue, H.D. (2008): Palaeomicrobiology of Tuberculosis. In: Raoult, D., Drancourt, M. (Eds) Paleomicrobiology: Past Human Infections. Springer International Publishing AG. pp. 75-97.

Donoghue, H.D., Marcsik, A., Matheson, C., Vernon, K., Nuorala, E., Molto, J.E., Greenblatt, C.L., Spigelman, M. (2005): Co-infection of Mycobacterium tuberculosis and Mycobacterium leprae in human archaeological samples. Proceedings of the Royal Society of London B, (272): 389-394. DOI: $10.1098 / \mathrm{rspb} .2004 .2966$

Dutour, O. (2008): Archaeology of Human Pathogens: Palaeopathological Appraisal of Palaeoepidemiology. In: Raoult, D., Drancourt, M. (Eds) Paleomicrobiology: Past Human Infections. Springer International Publishing AG. pp. 125-144.

Évinger, S., Bernert, Zs., Fóthi, E., Wolff, K., Kővári, I., Marcsik, A., Donoghue, H.D., O’Grady, J., Kiss, K.K., Hajdu, T. (2011): New skeletal tuberculosis cases in past populations from Western Hungary (Transdanubia). HOMO Journal of Comparative Human Biology, 62: 165-183. DOI: $10.1016 /$ j.jchb.2011.04.001

Fletcher, H.A., Donoghue, H.D., Holton, J., Pap, I., Spigelman, M. (2003): Widespread occurrence of Mycobacterium tuberculosis DNA from 18th-19th century Hungarians. American Journal of Physical Anthropology, 120: 144-152. DOI: 10.1002/ajpa.10114

Kustár, Á., Pap, I., Végvári, Zs., Kristóf, L.A., Pálfi, Gy., Karlinger, K. Kovács, B., Szikossy, I. (2011a): Using of 3D virtual reconstruction for pathological investigation and facial reconstruction of an 18th century mummified nun from Hungary. Yearbook of Mummy Studies, 1: 83-93.

Kustár, Á., Pap, I., Végvári, Zs., Kristóf, L.A., Pálfi, Gy., Karlinger, K., Kovács, B., Szikossy, I. (2011b): Tauber Antónia, 18. századi váci apáca múmiájának patológiai vizsgálata és arcrekonstrukciója, 3D rekonstrukciós módszerek alkalmazásával. Anthropologiai Közlemények, 52: 5-15.

O'Rourke, D.H., Hayes, M.G., Carlyle, S.W. (2000): Ancient DNA studies in physical anthropology. Annual Review of Anthropology, 29: 217-242. DOI 10.1146/annurev.anthro.29.1.217

Pap, I., Susa, É., Józsa, L. (1997): Mummies from the 18th-19th century Dominican Church of Vác, Hungary. Acta Biologica Szegediensis, 42: 107-112.

Pap, I., Józsa, L., Repa, I., Bajzik, G., Lakhani, S.R., Donoghue, H.D., Spigelman, M. (1999) 18-19th century tuberculosis in naturally mummified individuals (Vác, Hungary). In: Pálfi, Gy., Dutour, O., Deák, J., Hutás, I. (Eds) Tuberculosis: Past and Present. Budapest Szeged. pp. 419-428.

Pálfi, Gy., Zink, A., Maixner, F., Pósa, A., Lovász, G., Wicker, E., Bereczki, Zs., Molnár, E. (2012): Egy késő-középkori embertani széria tuberkulózis fertőzöttségének vizsgálata morfológiai és molekuláris biológiai módszerekkel. Anthropologiai Közlemények, 53: 35-50.

Poinar, H.N., Hofreiter, M., Spaulding, W.G., Martin, P.S. Stankiewicz, B.A., Bland, H., Evershed, RP., Possnert, G., Paabo, S. (1998): Molecular coproscopy: dung and diet of the extinct ground sloth Nothrotheriops shastensis. Science, 281: 402-406. DOI: $10.1126 /$ science.281.5375.402

Schmidt-Schultz, T.H., Schultz, M. (2004): Bone protects proteins over thousands of years: extraction, analysis, and interpretation of extracellular matrix proteins in archaeological skeletal remains. American Journal of Physical Anthropology, 123: 30-39. DOI: 10.1002/ajpa.10308

Schultz, M. (2001): Paleohistopathology of bone. A new approach to the study of ancient diseases. Yearbook of Physical Anthropology, 44: 106-147. DOI: 10.1002/ajpa.10024 
Susa, É. (1995): Előzetes jelentés a váci Fehérek temploma kriptafeltárásáról. Anthropologiai Közlemények, 37: 192-193.

Susa, É., Józsa, L. (1995): A múmiakészítés technikája és eredményei az ókortól napjainkig. Anthropologiai Közlemények, 37: 100-118.

Szikossy, I., Bernert, Zs., Pap, I. (1997): Anthropological investigation of the 18th-19th century ossary of the Dominican Church, Vác, Hungary. Acta Biologica Szegediensis, 42: 145-150.

Szikossy, I., Pálfi, Gy., Molnár, E., Karlinger, K., Kovács, B.K., Korom, Cs., Schultz, M., Schmidt-Schultz, T.H., Spigelman, M., Donoghue, H.D., Kustár, Á., Pap, I. (2015): Two positive tuberculosis cases in the late Nigrovits family, 18th century, Vác, Hungary. Tuberculosis, 95 (Suppl. 1): S69-S72. DOI: 10.1016/j.tube.2015.02.015

Tragor Ignác Múzeum (1995) A váci Fehérek temploma feltárási dokumentációja. ND 95.3.2.1262.

Zink, A., Haas, C.J., Reischl, U., Szeimies, U., Nerlich, A.G. (2001): Molecular analysis of skeletal tuberculosis in an ancient Egyptian population. Journal of Medical Microbiology, 50: 355-366. DOI: 10.1099/0022-1317-50-4-355

Zomborka, M. (1996): Vác „Fehérek temploma” kriptafeltárás. 1994-95. Magyar Múzeumok, 2(1): 3-7.

Levelezési cím: $\quad$ Pap Ildikó

Mailing address: $\quad$ Embertani tár

Magyar Természettudományi Múzeum

Ludovika tér 2-6.

H-1082 Budapest

Hungary

pap.ildiko@nhmus.hu 
